\title{
Recreation Safety Climate Measurement Tool: A Study of Adaptation to Turkısh, Validity and Reliability
}

\section{Kursad Sertbas, Muhammet Eyup Uzuner}

Department of Physical Education and Sports Teaching, Kocaeli University, Kocaeli, Turkey

Study Area: Kocaeli, Turkey

Coordinates: $40.852^{\circ} \mathrm{N} 29.878^{\circ} \mathrm{E}$

Key words: Risk perception, Situational engagement, Attachment to place, Resting place, Loyalty

T.C. Ethics committee approval was obtained from Kocaeli University - Social and Human Sciences Ethics Committee, dated 23.05.2019, and numbered 40224.

\section{Introduction:}

Due to the change in leisure time values in recent years, leisure activities have become very important in the lives of individuals. However, these activities carry some risks. Bentley et al. (2001) state that hiking and skiing are the activities most prone to accidents in New Zealand, accounting for $20 \%$ to $22 \%$ of accidents and fatalities in recreational activities. Hall \& McArthur (1991) state that $70 \%$ of individuals participating in rafting activities in Australia were injured. It has been reported that approximately $25 \%$ of adults have been exposed to at least one recreational activity injury (Grimmer et al., 2000). Therefore, it is clear that recreational activities involve many risks, and finding ways to reduce these risks is an important issue for recreational safety management.

In evaluating the safety situation of a place that is used extensively, the method of measurement through individual perception is used (Cooper \& Phillips, 1994; Neal et al., 200o). This method conceptualizes the safety climate from the perspective of organizational behaviour that is, the perception of the value and importance of safetyrelated policies, procedures, and practices among the organization or group members (Griffin \& Neal 200o). Cheng et al. (2016) introduced the concept of recreational safety climate by applying this method to recreational activities. This concept shows the extent to which a management unit invests in safety conditions as perceived by a recreational activity participant at a given time within the framework of the perception of recreational safety values, safety attitude, and safety measures. In addition, this study makes the safety climate measurable. It has reliability and validity to measure the safety climate of

\section{Abstract}

The purposeful sampling technique was used in the sample selection process to conclude this study. A total of $n=300$ individuals ( 143 females and 157 males) participated in the paragliding (tandem) activity in Muğla province, Fethiye district, Ölüdeniz neighbourhood has voluntarily participated in the study. The reliability coefficient (Cronbach's Alpha) of the measuring tool consisting of 26 items and, eight factors are in the range of $0,7 \leq \alpha<0,9$, which has been described as good. The result shows that the Turkish version of the Recreation Safety Climate Measurement Tool is a valid and reliable measurement tool.

recreation areas and can help recreational activity participants know the situation clearly and determine the degree of safety in the activity locations. Recreational safety measures are to ensure the quality of the recreational experience.

Based on this information, some studies attempt to model the consequences of the recreational safety climate for the safety of activity participants. According to previous studies; risk perception, situational engagement, satisfaction, attachment to place, and resting place loyalty are important variables in measuring recreation perception (Fave et al., 2003; Havitz \& Mannell 2005). The main purpose of the management is how the participants feel safe for the recreational activity organizers. Clarifying the relationship between the recreational safety climate and recreation perceptions states that it will help the organizer adjust recreational safety issues to reduce their perceptions of recreational risk. It is also integrated into the activities to create a sense of safe atmosphere, increase the recreational satisfaction of the participants, and provide feedback on recreation site commitment and loyalty. Recreational activities are very suitable for many safety problems before, during, and after the activity. However, a positive implementation of the risk management system can prevent many accidents that may occur and cause injuries (Zakaria et al., 2016).

Functional risk is when the product or service does not function as it was designed, offered, and promoted. Therefore, it states that it cannot provide the desired performance. Improper use or presentation of some products or services creates a hazard for the health or safety of the consumer and a physical risk factor emerges (Özer \& 
Gülpınar, 2005).

Paragliding: an adventure sport that can be performed individually and in tandem (accompanied by a pilot) with a specially produced parachute. Paragliding, which was first discovered in 1940, has become popular after the 1980s (Gauler et al., 2006; Schulze et al., 2002). In Turkey, the 1990's Mugla province in the early part of the year, the Fethiye district of Baba in Oludeniz Mountains from connecting Belcekiz Beach flights began ended in (Canbek et al., 2015).

Paragliding injuries occur less frequently than injuries occurring in other branches. However, the number of accidents that usually cause high-energy trauma and even death tends to increase in relation to the increasing number of flights (Fasching, 1997; Schulze et al., 200o). Canbek et al. (2015) emphasized that accidents occurring especially in the Fethiye region tend to increase due to insufficient precautions, and found the accident rate as 0.26 in 1000 and fatal accident rate as 7 in 100000 . It is also stated that individual paragliding activity is more prone to accidents than tandem paragliding type. Fasching et al. (1997) found this mortality rate of 45 per 1000ooo; Schulze et al. (2000) 0.7\%; Krüger-Franke et al. (1991); Amamilo et al. (1987) found it to be $0.06 \%-0.035 \%$. It is also stated that the accidents that occur are caused by human-induced errors and weather conditions (Mekinc \& Mušič 2016). According to the findings of a study examining the moment of occurrence of accidents in paragliding activity; $60 \%$ landing occurs, $26 \%$ take-off, and $14 \%$ during the flight (Lautenschlager et al. 1993). It is stated that accident rates that may result in injury or death that may occur during paragliding activity can be reduced by using appropriate equipment (Schmidt et al., 2005; Knapik et al., 2010).

For these reasons, the aim of the study is to provide a measurement tool to the Turkish literature to determine and improve the recreation safety climate level, especially in the paragliding branch.

\section{Methodology:}

This research; is applied in terms of basic philosophy, explanatory in terms of purpose, quantitative and screening in terms of method, cross-sectional in terms of duration, and individual in terms of the unit of analysis.

While the research was selected locally, the places where paragliding activity is most intensive in terms of user participation has been tried to be considered. Because of this reason; Muğla province, Fethiye district, Ölüdeniz Mahallesi, Denizpark Street, Belcekız Beach - Southeast side, this region has been chosen as the sampling point where paragliding activities end.

The universe of the research consists of individuals participating in the paragliding activity (tandem) accompanied by a pilot. A purposeful sampling technique was used in sample selection. While using a purposeful sampling technique, individuals who participated in the paragliding activity with a pilot were included in the study rightafter theactivity.

MacCallum et al. (2001) state that reaching a sample size of 4 times the number of items would be sufficient. However, DeVellis (2014) described the sample size as 200 peopleas a medium, 300 as good, 500 as very good, 1000, and above as excellent. It is accepted by most researchers that the sample size should be at least 5 times the number of items (Büyüköztürk, 2017). It was stated that a samplegroup around 10 times the number of observed variables would be sufficient in studies where structural equation modelling would be conducted (Ullman, 2006). This information indicates that the application of the 27-question inventory to a sample of 300 people has reached a sufficient number of samples in terms of statistics.

RSCMT (Recreation Safety Climate Measurement Tool): it was developed by Cheng et al. (2016) used to determine the participants' functional risk perceptions about the paragliding branch. Before the scale was used, necessary permission was obtained from the relevant author for use via e-mail. The scale consists of 27 questions and eight factors.

RSCMT (Recreation Safety Climate Measurement Tool) The stages of adapting into Turkish

- Scaleadaptation decision

- Translation of the scale into the target language (commission of at least two people)

- Back-translation (commission for at least two people)

- Seeking expertopinion (minimum two-person commission)

- Testing for reliability and validity (Cronbach Alpha, Confirmatory Factor Analysis and Explanatory Factor Analysis as required).

- $\quad$ Testing method and item bias (Bayık ve Gürbüz 2016).

During the translation phase, the following procedure was followed:

First of all, the original scale was translated from English to Turkish by an expert working in the field of physical education and sports with three Ph.D. degrees with high levels of English proficiency. The items of these translations were compared and the translation items with the same content were determined. Later, the Turkish draft was translated back into English by three Americans with high Turkish proficiency levels. The final version of the scale was created by comparing the obtained English draft and the original form, and by including the translation that best represents each item according to their similarities.

A personal information form was used to collect personal data of the individuals participating in the study. In this form; There are 6 questions about age, gender, occupation, monthly income, the region of residence, and whether the reason for the visit is only the relevant activity. No credentials were requested from the participants.

The data were analyzed in AMOS 24 and SPSS 25 
package programs. Confirmatory factor analysis was performed in the AMOS 24 package program. Descriptive statistical calculations (frequency, percentage, mean and standard deviation), exploratory factor analysis, and reliability analysis were performed in the SPSS 25 package program.

\section{Result:}

A total of 300 people who took part in the paragliding activity with an instructor participated in the study. Ages of the participants; the lowest 19 , the highest 58 , and the average $37.5 \pm 11.69$.

Monthly income levels of the participants; the lowest o Turkish Liras, the highest 15000 Turkish Liras, the average

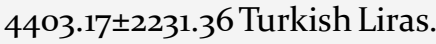

Table 2. Comparison of Finger Lengths According to Branches

Table-1: Distribution of Individuals Participating in the Paragliding Activity

\begin{tabular}{|c|c|c|c|c|c|c|}
\hline Variable & Parameter & $\bar{N}$ & $\%$ & Parameter & $\mathrm{N}$ & $\%$ \\
\hline Gender & Female & 143 & $47 \cdot 7$ & Male & 157 & 52.3 \\
\hline Age Group & 19 - 29 age & 90 & 30 & $30-6 o$ age & 210 & 70 \\
\hline Working & Not working & 10 & $3 \cdot 3$ & Public empl. & 67 & 22.3 \\
\hline \multirow[t]{2}{*}{ Status } & Private sect. & 162 & 54 & Employer & 28 & 9.3 \\
\hline & Student & 29 & $9 \cdot 7$ & Retired & 4 & 1.3 \\
\hline Monthly & $<2020$ も & 39 & 13 & 2021-4040も & 94 & 31.3 \\
\hline Income & 4041-6o6o も & 90 & 30 & $>6061 も$ & 77 & 25.7 \\
\hline The Region of & East Anatolian & 21 & 7 & Cent. Anatolia & 42 & 14 \\
\hline \multirow[t]{3}{*}{ Residence } & Black Sea & 32 & 10.7 & Mediterranean & 55 & 18.3 \\
\hline & Aegean & 65 & 21.7 & Marmara & 73 & $24 \cdot 3$ \\
\hline & $\begin{array}{l}\text { Southeastern } \\
\text { Anatolia }\end{array}$ & 12 & 4 & & & \\
\hline $\begin{array}{l}\text { Specifically } \\
\text { for this activity }\end{array}$ & Yes & 145 & 48.3 & No & 155 & 51.7 \\
\hline
\end{tabular}

Table- is self explanatory.

According to the results of Recreation Safety Climate Measurement Tool KMO and Bartlett's sphericity analysis, the KMO (Kaiser-Meyer-Olkin Measure of Sampling Adequacy) value of 0.792 indicates that the sample is quite sufficient for factor analysis. This value must be at least o.6o. Bartlett's Test of Sphericity result $($ Sig. $=0.000)$ means that the matrix formed by the relationships between variables is significant for factor analysis and factor analysis can be performed (Gürbüz and Şahin 2018).

One of the most important components of factor analysis is Eigen value. Eigen value greater than 1 is a necessary and sufficient condition for reliability to receive a positive value (Kaiser, 1974). As a result of the analysis, the items were distributed among the factors they belonged to following the original form of the measuring tool. In this study; the highest Eigen value was 6.06 and the lowest eigenvalue was 1.52 . The total variance value of the Recreation Safety Climate Measurement Tool was found to be $78.41 \%$. The measuring tool can explain the desired result with an accuracy of $78.41 \%$ (Table-2).
Table-2: The Results of the Exploratory Factor Analysis of the Recreation Safety Climate Measurement Tool

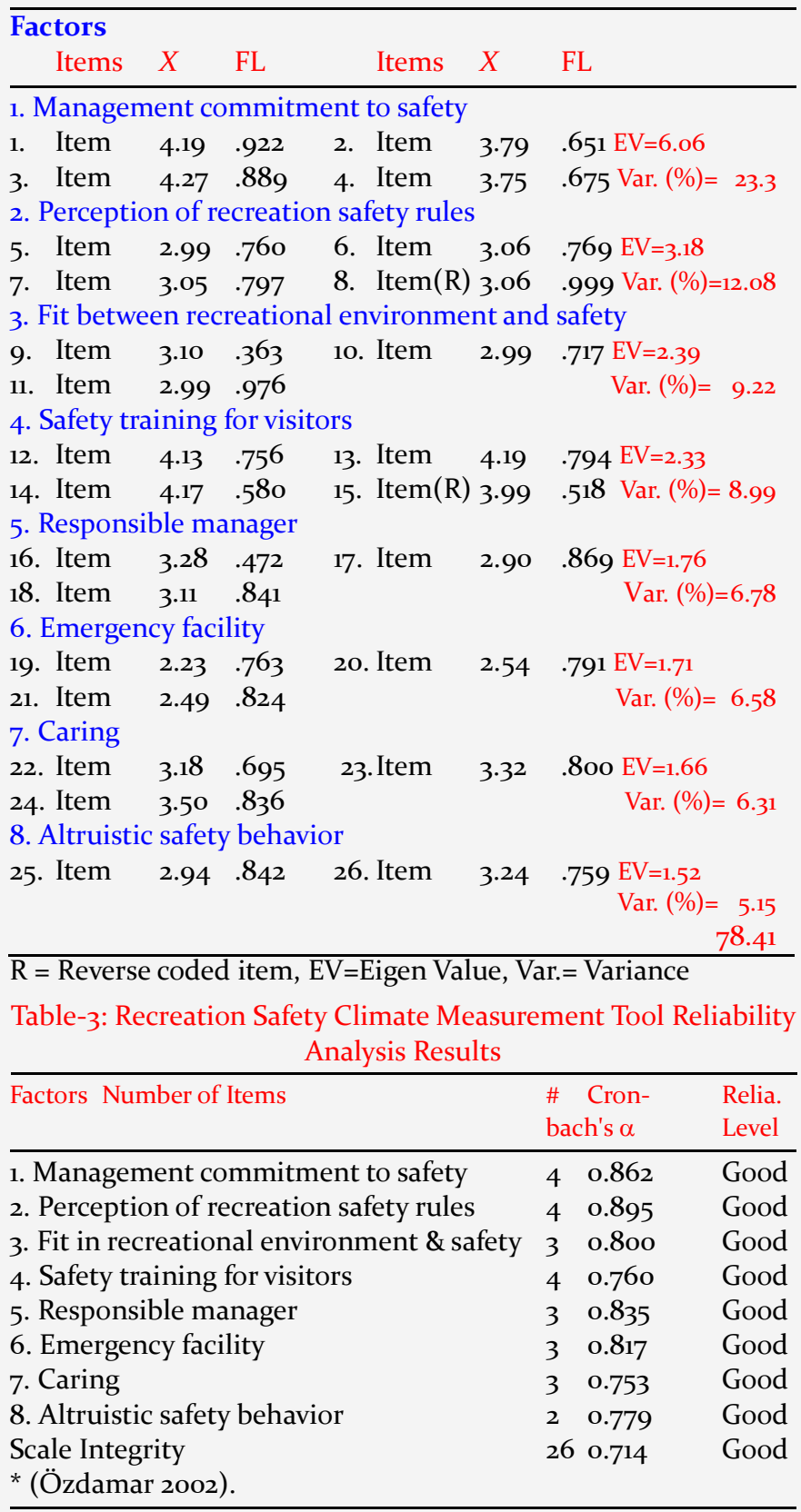

As per the results of the recreation safety climate measurement tool reliability analysis; all factors of the measuring tool areat a good level in terms of reliability and reliable (Table-2).

IAccording to the acceptable and normal values of the goodness of fit indices used in the confirmatory factor analysis (Munro, 2005; Schreiber et al., 2006; Hooper et al., 2008; Schumacker \& Lomax 2010; Wang \& Wang 2019), the values found in the study; It can be said that the factorial structure of the Recreation Safety Climate Measurement Tool is supported by research data, in other words, verified.

The validity of a scale is evaluated by discriminating validity and structural fit validity. Structural conformity validity expresses whether the factor loads of all items are important (Bagozzi et al., 1991). AVE values for all dimensions vary between 0.58 and 0.83 , 
exceeding the criterion 0.50 (Fornell \& Larcker 1981). This shows that the confirmatory factor analysis results support the structural validity conditions of the scale.

In the fit factor of the scale numbered 3 between recreational environment and safety; This place is unsuited to diving activities, making me feel fearful. The substance was removed from the scale in line with the reliability analysis results because it could not provideappropriate data on paragliding activity.

Recreation Safety Climate Measurement Tool According to Pearson correlation results; There is a very strong positive correlation at the level of $0.7<\mathrm{r} \leq 1$ with the factors they belong to. These results indicate that the items of the measuring tool accurately represent the factors they belong to.

Table-4: Confirmatory factor analysis results of recreation safety climate measurement tool

\begin{tabular}{|c|c|c|c|c|c|c|c|}
\hline $\begin{array}{l}\text { Factor } \\
\text { Items }\end{array}$ & FL & SMC & & Items & FL & SMC & \\
\hline 1. Managen & ent cor & mitme & nt to & safety & & & \\
\hline 1. Item & 0.875 & 0.85 & 2. & Item & 0.736 & 0.71 & $\mathrm{CR}=.88$ \\
\hline 3. Item & 0.866 & 0.84 & & Item & 0.783 & 0.76 & $\mathrm{AVE}=.66$ \\
\hline 2. Perceptic & $\mathrm{n}$ of rec & eation & safet & y rules & & & \\
\hline 5. Item & 0.845 & 0.82 & 6. & Item & 0.844 & 0.49 & $C R=.92$ \\
\hline 7. Item & 0.848 & 0.82 & 8. & Item & 0.949 & 0.92 & $\mathrm{AVE}=.76$ \\
\hline 3. Fit betwe & en recr & ational & envir & ronme & th and s & fety & \\
\hline 9. Item & 0.783 & 0.76 & 10. & Item & 0.966 & 0.94 & $\mathrm{CR}=.93$ \\
\hline 11. Item & 0.961 & 0.93 & & & & & $\mathrm{AVE}=.83$ \\
\hline 4. Safety tra & ining $\mathrm{f}$ & visito & & & & & \\
\hline 12. Item & 0.786 & 0.76 & 13. & Item & 0.826 & 0.80 & $C R=.85$ \\
\hline 14. Item & 0.724 & 0.70 & 15. & Item & 0.768 & 0.75 & $\mathrm{AVE}=.60$ \\
\hline 5. Responsi & ble mar & ger & & & & & \\
\hline 16. Item & 0.703 & 0.68 & 17. & Item & 0.770 & 0.75 & $\mathrm{CR}=.8 \mathrm{o}$ \\
\hline 18. Item & 0.814 & 0.79 & & & & & $\mathrm{AVE}=.58$ \\
\hline 6. Emergen & cy facili & & & & & & \\
\hline 19. Item & 0.737 & 0.72 & 20. & Item & 0.81 & 0.79 & $\mathrm{CR}=.83$ \\
\hline 21. Item & 0.817 & 0.79 & & & & & $\mathrm{AVE}=.62$ \\
\hline 7. Caring & & & & & & & \\
\hline 22. Item & 0.777 & 0.75 & 23. & Item & 0.793 & 0.77 & $\mathrm{CR}=.83$ \\
\hline 24. Item & 0.792 & 0.77 & & & & & $\mathrm{AVE}=.61$ \\
\hline 8. Altruisti & safety & ehavio & & & & & \\
\hline 25. Item & 0.766 & 0.74 & 26. & Item & 0.824 & 0.80 & $\begin{array}{l}\mathrm{CR}=.77 \\
\mathrm{CR}=.63\end{array}$ \\
\hline
\end{tabular}

SMC=Squared multiple correlations; $C R=$ Composite Reliability; AVE=Average variance extracted

\section{Discussion :}

The recreation safety climate is mainly created by the management unit of the recreation area, including both private and public units. In-depth interviews were conducted to ensure that the recreational safety climate can be generalized by all management units to create a climate perception and to collect comprehensive data on recreational safety climate concepts by different participants. Afterwards, content analysis was conducted to understand the recreation safety climate dimensions. Scale items were determined by exploratory factor analysis, and scale reliability and validity were confirmed by confirmatory factor analysis. As a result, the recreation safety climate scale consists of eight dimensions and 26 measurement items. The eight dimensions are as follows: management safety commitment, perception of recreation safety rules, compliance between recreational environment and safety, safety training for participants, responsible manager, emergency facility, attentiveness, and caring safety behaviour.

First, the management safety commitment dimension shows to what extent the participants perceive the commitment of the management unit to safety in recreational activities. For example, it includes providing qualified licensed professionals, regular maintenance and repair of recreational facilities and equipment, and a commitment to keeping audit records to increase participants' confidence in recreation operators and assist them to engage in activities with peace of mind. Abudayyeh et al. (2006) observed that the more managers meet the safety requirements, the more people feel safer. This shows the importance of security commitment at scale.

The second dimension, the perception of recreation safety rules, refers to the ability of the activity participants to understand that the safety rules and procedures determined by the managers are sufficient to ensure recreational safety. An atmosphere of safety and order can be created if a recreation place provides safety-compliant equipment and protective equipment for the use of participants, if management units effectively monitor and enforce regulations, help participants understand recreational activity rules and procedures. This can also prevent accidents and effectively protect the participant's safety and rights while participating in an activity.

The third dimension means the harmony between the recreational environment and safety, the placement of clear safety signs in the space, and the adaptation of this area, and activity tends to feel safe. Ballantyne et al. (2005) stated that adequate recreational safety knowledge can increase participants' awareness of potential dangers and reduce the occurrence of accidents. When individuals involved in activities are able to clearly and easily perceive mounted warning signs and safety information, these signs provide a safety framework to follow and help identify hidden risks. In addition, a clear separation of operational safety coverage and properly planned areas for different types of activity can help participants determine the safety compliance of the activity and the environment. It can also enable participants to perceive that the location and activity are adapted to accommodate safety conditions.

For the participants, the fourth dimension, safety training refers to the advanced safety training provided by the management unit to the participants and whether it makes the participants feel that they have sufficient knowledge and skills to operate effectively. For example; Teaching the skills and knowledge of activities that help safe demonstration and recreation to respond to a variety of safety concerns. Therefore, safety training for participants 
TECHNOSCIENCE ARTICLE

is a vital dimension to ensure participant safety.

The fifth dimension, the responsible manager, allows the participants to monitor situations within the safety responsibility of the manager (having a legal license for the application, taking into account the safety of the recreational environment, and closely monitoring the safety quality of the activity). This dimension is also consistent with the safety climate dimensions previously determined in other areas. Varonen \& Mattila (2000) state that the responsibility of the manager and previous safety measures affect the level of safety felt by a person in an environment. Therefore, it shows that acting with a sense of responsibility is an important aspect of the safety climate. The sixth dimension, emergency facilities, expresses the participants' perception that the manager provides healthy emergency facilities and assures them when dealing with activities. The emphasis on emergency facilities is the manager's ability to provide an immediate rescue process when accidents occur. This can provide psychological and significant safety benefits to the participant.

The seventh dimension, caring, means that the participant can feel safe directly through another person. The involvement of a companion can increase the participant's perception of safety through psychological support, such as encouragement and support from an instructor, and reducing anxiety.

Finally, the contemplative behaviour dimension refers to the participants who pro-actively assist other participants and alert others to safety measures. When participants act devotedly, by warning others of danger, absolutely preventing others from engaging in unsafe behaviour, or when warnings carelessly inform relevant units, they can not only help others avoid danger but also have a self-help effect. This study provided a reliable and valid recreation safety climate scale. Recreation management units can use this scale to objectively assess participants' true perception of the safety climate in an area of activity. This makes sense for safety management in a number of ways.

First, recreation management units can use this scale as a recreation safety diagnostic tool. A safety climate may change according to the circumstances, so it is necessary to re-evaluate such situations repeatedly. When managers identify a low level of safety climate perception, they can immediately adjust and improve the relevant facility safety quality to maintain participant safety.

Second, this tool can also offer a safety audit function for an organization. Managers can enable instructors to participate in learning events or safety training seminars to improve their professional knowledge and skills, as well as design safety training and training courses for recreational professionals, such as presenting and demonstrating information. It can be ensured that activities with different contents can be organized according to needs (eg walking or scuba diving). Through safety training for participants,
Ambient Science, 2020: Vol. 07(Sp1); 345-350 DOI:10.21276/ambi.2020.07.sp1.ta16

managers can be aware of whether participants are obeying safety rules when participating in recreational activities. It can also help participants understand the specifics of recreational activity, make safety self-assessments, and reflect on participant safety issues.

Third, recreation safety climate measurement instrument dimensions are meaningful as safety indicator structures. Management units can consider all eight dimensions of this tool as an important security indicator structure for ground safety. Dimensional elements can provide a basis for the specific handling of safety issues, thereby facilitating a better environment for the perception of the safety climate. An example of this is to establish activity rules and guidelines that define the safe range for each type of activity, establish safety signs, provide safety information, and design safety procedures for events. As a result, recreation can ensure safety through the establishment of rules that participants and professionals must follow during activities. Another example is building a safety rescue control centre to provide emergency rescue systems and medical rescue services to protect the safety of participants in an activity.

Conclusions and Recommendations:

In this study, which aims to provide a measurement tool to the Turkish literature for determining and improving the perception of recreation safety climate in sports recreational activities, especially in the paragliding branch, the Recreation Safety Climate Measurement Tool, developed by Cheng et al. (2016) which has been brought to the literature as a valid and reliable measurement tool with the name of the tool.

It is very important to bring the safety climate to a measurable level, especially since recreational activities are open to situations where accidents that may result in injury and even death can occur in many ways. It is stated that this measurement process can be done most healthily through the safety perception of the participants. Confirmatory factor analysis results reveal that the eight-factor structure of the scale shows an acceptable model fit. The internal reliability values of these factors and the discrimination power of the scale were found to be high. Research results, Recreation Safety Climate Assessment Tool recreation perceptions of safety climate measurement and is a valid and reliable instrument that can be used to assess and Turkey's shows can be used in recreational activities.

Many past studies of the safety climate confirm the positive impact of the safety climate on safety behaviour and safety performance. It is suggested that future research should examine the relationship between risk perception, recreation experience, recreation satisfaction, recreation benefits, and other relevant variables.

\section{References:}

Abudayyeh, O., Fredericks, T.K., Butt, S.E., \& Shaar, A. (2006): An Investigation of Management's Commitment to Construction 
Safety. Int. J. Project Manag., 24(2):167-174.

Amamilo, S.C., Samuel, A.W., Hesketh, K.T. \& Moynihan, F.J. (1987): A Prospective Study of Parachute Injuriesin Civilians. L. Bone Joint Surg. Br., 69(1):17-19.

Bagozzi, R.P., Yi, Y. \& Singh S. (1991). On the Use of Structural Equation Models in Experimental Designs: Two Extensions. Int. J. Res. Market, 8(2):125-140.

Ballantyne, R., Carr, N. \& Hughes, K. (2005): Between the Flags: An Assessment of Domestic and International University Students' Knowledge of Beach Safety in Australia. Tour. Manag., 26(4):617-622.

Bay1 k, M.E. \& Gürbüz, S. (2016): Ölçek Uyarlamada Metodoloji Sorunu: Yönetim ve Örgüt Alanı nda Uyarlanan Ölçekler Üzerinden Bir Araştırma. İs ve İnsan Dergisi, 3(1):1-20.

Bentley, T.A., Page, S.J. \& Laird, I.S. (2001): Accidents in the New Zealand Adventure Tourism Industry. Safety Sci., 38(1):31-48.

Büyüköztürk, Ș., Çakmak, E.K., Akgün, Ö.E., Karadeniz, Ș. \& Demirel, F. (2017): Bilimsel Araştırma Yöntemleri. Pub. by: Pegem Akademi, Ankara.

Canbek, U., İmerci, A., Akgün, U., Yeşil, M., Aydın, A. \& Balci, Y. (2015): Characteristics of Injuries Caused by Paragliding Accidents: A Cross-Sectional Study. World J. Emerg. Med., 6(3):221.

Cheng, T.M., Chen, M.T. \& Hong, C.Y. (2016): Conceptualizing and Measuring Recreation Safety Climate. Safety Sci., 87:224-233.

Cooper, M.D. \& Phillips R.A. (1994): Validation of a Safety Climate Measure. Occup. Psychol. Conf. Br. Psychol. Soc., 3(5).

DeVellis, R.F. (2014): Ölçek Geliștirme:Kuram ve Uygulamalar. Pub. by: Nobel Akademik, Ankara.

Fasching, G., Schippinger, G. \& Pretscher, R. (1997): Paragliding Accidents in Remote Areas. Wilder. Environ. Med., 8(3):129133.

Fave, A.D., Bassi, M. \& Massimini, F. (2003): Quality of Experience and Risk Perception in High-Altitude Rock Climbing. J. Appl. Sport Psychol., 15(1):82-98.

Fornell, C. \& Larcker, D.F. (1981): Evaluating Structural Equation Models with Unobservable Variables and Measurement Error. L. Market. Res., 18(1):39-50.

Gauler, R., Moulin, P., Koch, H.G., Wick, L., Sauter, B., Michel, D. \& Knecht, H. (2006). Paragliding Accidents with Spinal Cord Injury: 10 Years' Experience at a Single Institution. Spine, 31(10):1125-1130.

Griffin, M.A. \& Neal, A. (200o): Perceptions of Safety at Work: A Framework for Linking Safety Climate to Safety Performance, Knowledge and Motivation. L. Occup. Health Psychol., 5(3):347.

Grimmer, K.A., Jones, D. \& Williams, J. (2000): Prevalence of Adolescent Injury from Recreational Exercise: An Australian Perspective. J.Adolescent Health, 27(4):266-272.

Gürbüz, S. \& Șahin, F. (2018): Sosyal Bilimlerde Araștırma Yöntemleri. Pub. by: Seçkin Yayıncılık, Ankara.

Hall, C.M. \& McArthur, S. (1991): Commercial White Water Rafting in Australia. Aus. J. Leisure Recreat., 1(2):25-30.

Havitz, M.E. \& Mannell, R.C. (2005): Enduring Involvement, Situational Involvement and Flow in Leisure and NonLeisure Activities. J.Leisure Res., 37(2):152-177.

Hooper, D., Coughlan, J. \& Mullen, M.R. (2008): Structural Equation Modelling: Guidelines for Determining Model Fit.
Elect.J. Busi. Res. Method., 6(1):53-6o.

Kaiser, H.F. (1974): An Index of Factorial Simplicity. Psychometrika, 39 (1):31-36.

Knapik, J.J., Spiess, A., Swedler, D.I., Grier, T.L., Darakjy, S.S. \& Jones, B.H. (2010): Systematic Review of the Parachute Ankle Brace: Injury Risk Reduction and Cost Effectiveness. Am. J. Prevent. Med., 38(1):182-188.

Krüger-Franke, M., Siebert, C.H., \& Pförringer, W. (1991): Paragliding Injuries. Br. J. Sports Med., 25(2):98-101.

Lautenschlager, S., Karli, U. \& Matter, P. (1993): Paragliding Accidents - A Prospective Analysis in Swiss Mountain Regions. ZUnfallchir Versicherungsmed, 55-65.

MacCallum, R.C., Widaman, K.F., Preacher, K.J. \& Hong, S. (2001): Sample Size in Factor Analysis: The Role of Model Error. Multivar. Behav. Res., 36(4):611-637.

Mekinc, J. \& Mušič, K. (2016): Elements of Safety in Paragliding. Annal. Kinesiol., 7(1):67-8o.

Munro, B.H. (2005): Statistical Methods for Health Care Research. Pub. by: Lippincott Williams and Wilkins, Philadelphia

Neal, A., Griffin, M.A., \& Hart, P.M. (200o): The Impact of Organizational Climate on Safety Climate and Individual Behavior. Safety Sci., 34(1-3):99-109.

Özdamar, K. (2002): Paket Programlarla İstatistiksel Veri Analizi. 4. Baskı. Pub. by: Kaan Kitabevi, Eskișehir.

Özer, L. \& Gülpınar, S. (2005): Hizmet Sektöründe Tüketicilerin Algıladıkları Riskler: Hava Yolları Sektöründe bir Araștırma.Ticaret ve Turizm Eğitim Fakültesi Dergisi, (1):1-15.

Schmidt, M.D., Sulsky, S.I. \& Amoroso, P.J. (2005): Effectiveness of an Outside-the-Boot Ankle Brace in Reducing Parachuting Related Ankle Injuries. Injury Prevent., 11(3):163-168.

Schreiber, J.B., Nora, A., Stage, F.K., Barlow, E.A. \& King, J. (2006): Reporting Structural Equation Modeling and Confirmatory Factor Analysis Results: A Review.J. Edu. Res., 99(6):323-338.

Schulze, W., Hesse, B., Blatter, G., Schmidtler, B. \& Muhr, G. (2000): Pattern of Injuries and Prophylaxis in Paragliding. Sportverletz Sportschaden, 14(2):41-49.

Schulze, W., Richter, J., Schulze, B., Esenwein, S.A. \& BüttnerJanz, K. (2002): Injury Prophylaxis in Paragliding. Br. J. Sports Med., 36(5):365-369.

Schumacker, R.E. \& Lomax, R.G. (2010): A Beginner's Guide to Structural Equation Modeling. Pub. by: Taylor and Francis, New York.

Ullman, J.B. \& Bentler, P.M. (2003): Structural Equation Modeling. İçinde (607-634); Irving B. Weiner (Editör) Handbook of Psychology Pub. by: John Wileyand Sons.

Varonen, U. \& Mattila, M. (200o): The Safety Climate and it's Relationship to Safety Practices, Safety of the Work Environment and Occupational Accidents in Eight WoodProcessing Companies. Accident Analysis Prevent., 32(6):761-769.

Wang, J. \& Wang, X. (2019): Structural Equation Modeling: Applications Using Mplus. Pub. by: John Wileyand Sons.

Zakaria, J., Harun, M.T., Salamuddin, N. \& Taff, M.A.M. (2016): Risk Management Practices Towards Developments of Sport and Recreational Activities in Malaysia. Open Acc. Lib. J., 3(7):1-11. 